\title{
Reconciling contradictory narratives of landscape change using the adaptive cycle: a case study from southeastern Australia
}

\author{
$\underline{\text { Andrea Rawluk }}^{1,2}$ and Allan Curtis ${ }^{1,2}$
}

\begin{abstract}
This paper addresses the methodological challenge of exposing and reconciling contradictory narratives of change in a social-ecological system (SES). Our research occurred in the Ovens Valley in southeastern Australia. Other studies have used the adaptive cycle to interpret change, but those efforts have been based on researcher-derived interpretations. We drew on the Factors Actors Sectors framework as a structure for coding qualitative interview data provided by key informants. Our analysis suggested that interpretations of SES change fell into three groups: farmers, employees of government and local organizations, and local politicians. Those narratives were then overlaid on the adaptive cycle as a way of exposing and interpreting the narratives. To farmers, the SES was based on agriculture and approaching collapse, and intervention was required to prevent a collapse. Employees of government and local organizations thought the SES had already collapsed, and local people were struggling to identify a prosperous new trajectory. The local politicians also thought the system had collapsed but unlike the other stakeholders, considered the SES as having already reorganized. We then drew on a range of secondary data to reconcile those contradictory narratives and form a consolidated interpretation of landscape change. Our synthesis of the primary and secondary data suggested that the SES had collapsed and reorganized as a multifunctional landscape. We suggest our approach may be useful to others attempting to interpret landscape change using a resilience framework. The case study also illustrates the importance of exploring multiple perspectives of landscape change as a way of exposing the role of power as a force shaping discourse and, therefore, policy and planning.
\end{abstract}

Key Words: adaptive cycle; landscape change; narratives

\section{INTRODUCTION}

Social researchers typically highlight the heterogeneity of perspectives and interests in rural landscapes (Agrawal and Gibson 1999, Kumar 2005, Reed et al. 2009, Gosnell and Abrams 2011). Given that heterogeneity, it is not surprising that local stakeholders often develop and advocate competing narratives of rural landscape change (Williams and Schirmer 2012). Over time, certain narratives may be privileged over others, reflecting and potentially reinforcing power relations (Flyvbjerg 1998, Fabinyi et al. 2014). This paper addresses the methodological challenge in social-ecological system (SES) research of how to expose and reconcile contradictory narratives of change. We in part respond to that challenge by using the adaptive cycle as an organizational and comparative heuristic. We reflect on the applicability of our use of the adaptive cycle and how it is labeled for social dynamics, and consider potential future uses.

Resilience thinking research assumes that change in an SES is ever present (Andersen and Jaeger 1999, Walker et al. 2002, Peterson et al. 2003, Walker and Salt 2012). Although scholars of many disciplines have embraced the assumption of continuous change, the incorporation of social dimensions into resilience thinking has been criticized for not adequately handling the dynamics and the complexities of society such as community heterogeneity, agency, and power (Davidson 2010, 2013).

The adaptive cycle is a heuristic for conceptualizing cyclical change in complex adaptive systems (Gunderson and Holling 2002). The adaptive cycle is arranged into four functional phases: exploitation, conservation, release, and reorganization: $r, K, \Omega$, and $\alpha$, respectively (Fig. 1). The system transitions between the $\mathrm{K}$ and $\Omega$ phases when observable thresholds are crossed (Walker and Meyers 2004). After the release phase $(\Omega)$, there are three possible directions for the system: resilience, adaptation, or transformation (Walker et al. 2006). The phases of $\Omega$ and $\alpha$ comprise what is referred to as the "back loop" of the adaptive cycle (Abel et al. 2006, Walker et al. 2006).

Fig. 1. The adaptive cycle heuristic (From Panarchy edited by L. H. Gunderson and C.S. Holling. Copyright (C) 2002 Island Press. Reproduced by permission of Island Press, Washington, DC.).

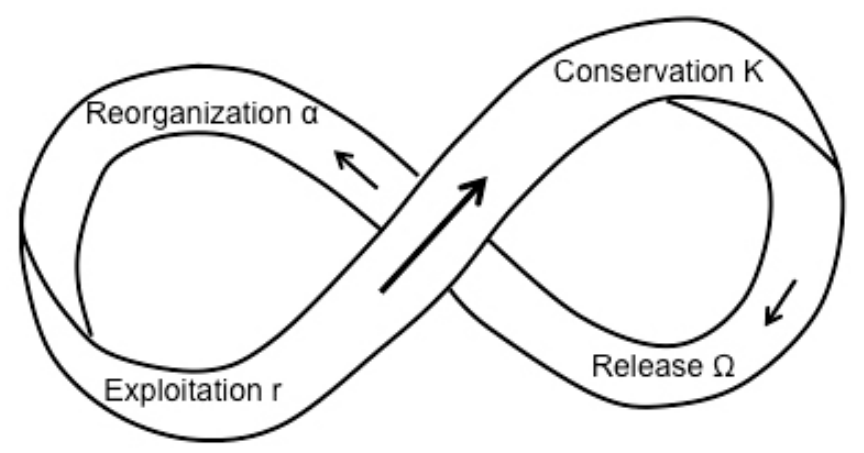

The adaptive cycle has been used for resilience assessments (Allison and Hobbs 2004, Walker et al. 2009, Lyon and Parkins 2013, Lockwood et al. 2014) and for exploring change over time in an SES (Allison and Hobbs 2004, Walker et al. 2009, Lockwood et al. 2014, Sinclair et al. 2014). In a number of cases, those researchers have used the adaptive cycle as a heuristic. For example, Sinclair et al. (2014) used the adaptive cycle to explore the nature of past SES change, including assessing whether the dairy industry had been transformed as a result of deregulation of the industry by government. Allison and Hobbs (2004), Walker et al. (2009), and Lockwood et al. (2014) used the adaptive cycle 
to explore possible future trajectories for an SES. Redman and Kinzig (2003) and Lockwood et al. (2014) examined long-term, slow change over a period of more than one century. Lyon and Parkins (2013) and Sinclair et al. (2014) looked at short-term change over a period of between 2 and 10 years. However, all of those studies have involved the creation of a single narrative of change, largely driven by the researcher(s). Therefore, that research provided useful, but eventually limited, guidance about how to expose and reconcile apparently contradictory narratives of change in an SES.

Responding to that challenge required two important innovations in the use of the adaptive cycle to interpret SES change. First, we needed to move from a single, researcher-focused interpretation of change and address the possibility of multiple interpretations of change. Second, we needed to interpret social change in a holistic manner rather than focus upon a particular industry or element of the SES.

Background: the Ovens catchment case study, Victoria, Australia We carried out this research in the Ovens catchment (the Ovens) in northeast Victoria, Australia. The initial objective was to examine local perspectives on a proposed food bowl development.

The Ovens is a three-hour drive northeast of the large metropolitan center of Melbourne (population 4.3 million; Fig. 2). It is a relatively small catchment in the Murray-Darling Basin, the food bowl of Australia, with an area of $7813 \mathrm{~km}^{2}$ and a population of 44,720 in 2011 (Australian Bureau of Statistics 2011). The Ovens River begins in the higher altitudes of the Victorian Alps and continues approximately $100 \mathrm{~km}$ to the Murray River (Paech 2008). The climate is variable, with much higher rainfall in the alpine region (approximately $1000 \mathrm{~mm} /$ year) than on the plains (approximately $500 \mathrm{~mm} / \mathrm{year}$ ). Daytime temperatures vary with altitude and the seasons, but the lower elevations are typical of most midlatitude environments. The city of Wangaratta is the main economic and population center, with approximately 17,000 people in 2011 (Australian Bureau of Statistics 2011). There are smaller townships, including Bright, Myrtleford, and Rutherglen.

Fig. 2. Map of Ovens catchment, Victoria, Australia. The red line is the Hume Freeway that links Melbourne and Sydney.

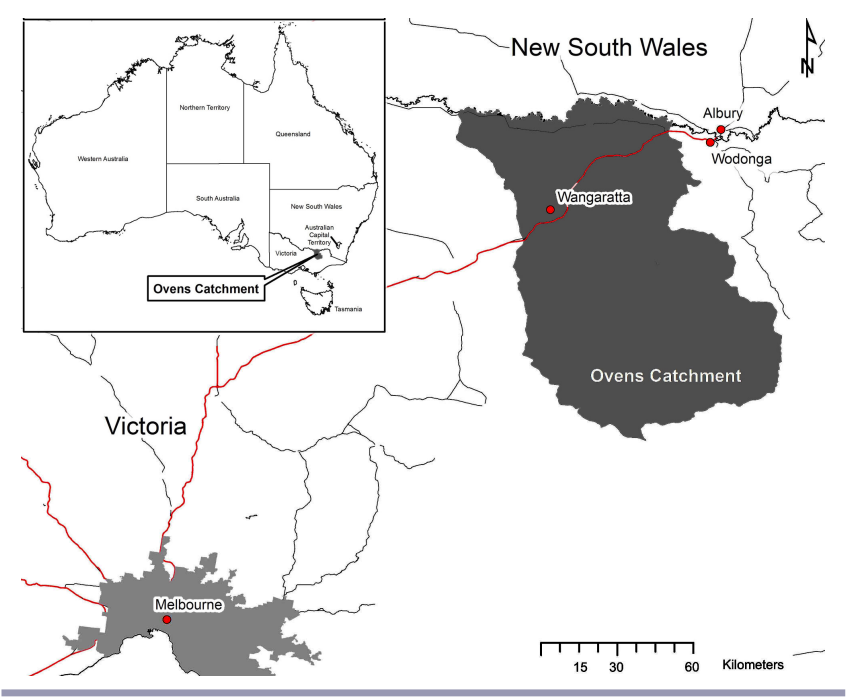

The Ovens was first explored by Europeans in the 1820s and was quickly settled thereafter (Whittaker 1963). Historically, the local economy has been based on primary industries such as gold mining, agriculture (dryland and irrigated dairy, beef, horticulture and viticulture), and forestry (Whittaker 1963, Paech 2008). Between the 1930 s and early 2000 s, tobacco was a highly profitable industry. After the closure of the industry in 2006, great efforts to identify a similarly lucrative agricultural industry have been unsuccessful (TAFCO 2008, 2009).

At the time of the study, local stakeholders and government had proposed the development of a food bowl underpinned by a significant expansion of irrigation. Particular attention had been given to attracting outside investment to the region (Wangaratta and Alpine Shire 2010). The food bowl concept was based on several assumptions. These included growing world demand for high-quality food; proximity of the Ovens to rail and road transport to Melbourne and Sydney; substantial areas of relatively flat land mostly used for low-value commodities such as beef cattle; and substantial volumes of underutilized surface water and groundwater, including potable water in a recently discovered large aquifer (Department of Environment and Primary Industry 2014).

The Ovens was most likely the only catchment in the MurrayDarling Basin with substantial, unused surface water and groundwater resources that were allocated for irrigation. For example, in the Upper Ovens in 2012, the average metered use for river diversions (surface water) was 2880 megaliters, versus the 5700 megaliters of entitlements available for use (GoulburnMurray Water 2012). In 2008, the use of groundwater in the Ovens was classified as low, with extraction estimated at only $7 \%$ of annual recharge (CSIRO 2008). In the Upper Ovens in 2012, the average metered use for groundwater extractions was 500 megaliters, versus the 1200 megaliters of entitlements available for use (Goulburn-Murray Water 2012).

\section{APPROACH}

We began the research with key informant interviews $(n=28)$. Interviewees were selected using a snowball sampling technique (Biernacki and Waldorf 1981), beginning with individuals known to the research team. The interview data were qualitative and collected using an interview guide in a conversational way (Kvale 1996). Informants tended to speak about 5- to 20-year time periods, which was similar to the time frame used by Lyon and Parkins (2013) and Sinclair et al. (2014). The interviews were transcribed (Poland 2002).

We used the Factors Actors Sectors (FAS) framework (Kok et al. $2006 a, b)$ as a deductive coding structure (Creswell 2009) to transform the data from each informant into a comparable data set. The FAS framework has been used in scenario planning research and provides a structure for coding stakeholder interpretations of a system into the features and characteristics of the factors, actors, and sectors that comprise that system (Kok et al. 2006a,b). We used NVivo 10 (QSR International) to organize and code the interview data (Richards 2009).

We compared interview data on past and present change, and identified three distinct narratives held by different informant types: farmers $(n=14)$, employees of government and local organizations $(n=12)$, and politicians $(n=2)$. The three narratives 
were contradictory. We overlaid each narrative onto the adaptive cycle, which enabled us to compare them.

To reconcile the contradictory narratives of change, we examined a range of secondary data including (1) data from the Australian Bureau of Statistics, (2) dissertation research that included the Ovens, and (3) local histories. These additional data added both breadth provided by additional topics and depth provided by descriptions of change over a longer time frame. We were also able to test the validity of evidence on which key informants based their interpretations. In this way, we were able to develop a consolidated interpretation of change in the SES.

The census data proved to be critical to our attempts to reconcile the contradictory narratives. We began with a broad list of 20 variables identified by Curtis et al. (2003) when they prepared a social profile (Sanders 1960) for an Australian watershed. Those variables provided measures of aspects of the human, social, and economic capitals thought to underpin capacity to implement natural resource management (Curtis et al. 2003, Gadsby et al. $2013 a, b)$. Data were readily available for the Ovens for 12 of the 20 variables identified by Curtis et al. (2003). From those, we identified four measures that contributed to our development of a consolidated interpretation of change in the Ovens SES. The four key variables were industry of employment, total population, rural balance population, and population age structure.

Our analysis of the census data was complicated because the Ovens includes parts of three shires or local government areas, which are a key geography for the presentation of census data. Those shires/local government areas are Alpine Shire, Indigo Shire, and the Rural City of Wangaratta. We did not include the urban population in Wangaratta in our calculations. Another complication was that we were interested in change over a substantial period of time. The Australian census occurs every five years, and there has been considerable variation in the items included in the census over the recent past. We settled on a $25-$ year period from 1986 to 2011 (the most recent census), which enabled us to match the national data sets with the lived experience of most of our informants. We also drew on the concept of rural balance (Curtis et al. 2003) to distinguish trends in the part of the Ovens outside the urban centers, including Wangaratta and the small towns. Given the limitations of space, we have only presented a summary of the most relevant data from the census data sets.

Other data for Indigo and Alpine Shires, i.e., two of three shires in the Ovens, and the nearby shire of Towong, i.e., outside the Ovens, were also important in developing our consolidated understanding of change in the Ovens SES. The key data were summaries of the origin of purchasers of rural land in those shires and statistics on the mean price paid per hectare for rural land sold during the period 1995 to 2005 (Stewart 2009). Stewart's (2009) doctoral research examined the extent to which farm forestry on private land was likely to occur in the amenity landscapes of southeastern Australia.

Similar to Lockwood et al. (2014), who set out to understand change as part of their resilience assessment of communities in the Australian Alps, we also drew on local documents for evidence of change in the Ovens (Bowen 2009). Those data included documents prepared by local government, consultants, news media, and local organizations. As part of our analysis of change, we compiled a time line spanning the period from 1820 to the present. The time line provided a much longer perspective than either the informant interviews or the Australian Bureau of Statistics data.

\section{FINDINGS}

Three contradictory informant narratives of past change and present interpretations of landscape

We uncovered three contradictory narratives of change organized around three informant, i.e., actor, groups: farmers, employees of government and local organizations, and politicians. Table 1 provides a compilation of quotations from each group summarizing their interpretation of Ovens SES change. Although employees of government and local organizations did not discuss the past, farmers and politicians described agriculture as the main economic activity in the Ovens and the basis of prosperity (quotes 1 and 12, Table 1) from European colonization until well into the 20th century. We interpret this period of agricultural expansion and prosperity as corresponding with the exploitation phase of the adaptive cycle.

Although farmers' and politicians' descriptions of the past were similar, their interpretations of change in recent times diverged. Farmers described an agricultural landscape that was currently responding to recent shocks and challenges, and expressed concern that the viability of agriculture was under threat. For these informants, the tobacco industry closure in 2006 was a major shock (quote 2) and the future of the region depended on identifying another profitable agricultural enterprise (quote 3). Farmers also discussed challenges resulting from global pressures (quotes 4 and 5) and the encroachment of lifestyle properties (quote 6). Farmers were anxious about the future, deeply distressed that young people were no longer staying in the region (quote 6), and concerned that the overall population was declining. This part of the farmers' narrative, when overlaid on the adaptive cycle, aligned with approaching the release phase $(\Omega)$. To these farmers, the SES was at the end of an agricultural era unless the emergence of a profitable enterprise prevented such a transition (Fig. 3).

Fig. 3. Overlay of farmers' narrative onto the adaptive cycle. The farmers' narrative of the local SES aligned with the phase of the adaptive cycle approaching collapse between $\mathrm{K}$ and $\Omega$. Farmers were concerned that very soon the local SES would no longer be an agriculture landscape. SES indicates socialecological system.

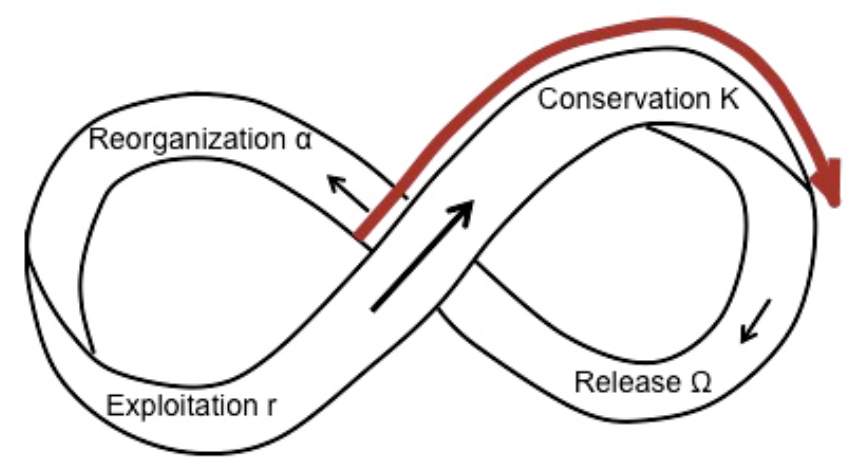


Table 1. Quotations from three informant groups that describe SES change differently. The informant groups were farmers, employees of government and local organizations, and politicians.

\begin{tabular}{ll}
\hline \hline $\begin{array}{l}\text { Informant } \\
\text { group }\end{array}$ & Quotations \\
\hline
\end{tabular}

Farmers

Quote 1. "This town [Myrtleford] was a tobacco town. The 60s-80s, where lots of money came in. People who grew tobacco could afford a new car every year and things like that. It was a very affluent community." (F07)

Quote 2. "[Tobacco growers have been] accustomed to having 1-3 families living off of one crop. Nothing is going to replace the industries." (F08)

Quote 3. "If an alternative crop could be found, the land is very fertile and could jump into life again. But, just at the moment, can I say, maybe doldrums would be the best word to use." (F07)

Quote 4. "Someone sneezes in America and we catch a cold." (F10)

Quote 5. "The issues that create our poor terms of trade are beyond the local area." (F09)

Quote 6. "That is just going to lead to forever, ongoing subdivision of land, and we will finish up with a whole lot of lifestyle blocks with 2 goats and 3 alpacas, and no areas where we can really be producing food for global use competitively. So it is a really concern to me, but I don't know how to change it." (F05)

Quote 7. "No longer can these areas support the up and coming generation... you have got to leave town and that makes me very sad. Because it would be lovely to keep those families here with you. It breaks up families." (F07)

Quote 16. "Most people need big blocks of land and they are all little blocks. And if they try to buy a number of little blocks of land to aggregate them, you can't actually just get the blocks that are adjacent to one another." (F05)

Employees of government and local organizations

Quote 8. "We saw all this rich land and high security and high quality water and people with rows and crops skills who are looking for an ongoing future in agriculture but who are a bit lost... we needed to get on to the investment radar... the opportunities for further agricultural transformation." (EGLO 10)

Quote 9. "We did lots of soil pits in the area and spent many thousands of dollars on what we knew: that we had really good dirt... We have sponsored farmers to go places to look at different industries... A couple years after the industry had ended nothing was happening, people weren't growing lucerne like they were, because we were in a drought... Pasture and hay production, beef cattle, by far, that is what the majority were doing, and then you see these odd, bizarre, little things: vegetable seed... pumpkin seed; zucchini flowers; green tea; a few berries." (EGLO 05)

Quote 10. "This land which is great soil, albeit mostly contaminated with organic chlorines, is very productive." (EGLO 04)

Quote 11. "A lot of what you are witnessing in [Wangaratta] is just the usual agrarian fundamentalism." (EGLO 13)

Politicians

Quote 12. "In the early 1900s, blocks got smaller and more people turned up... people [only needed] to have 20 or 30 cows, which was enough to make a bit of a living off of." (P02)

Quote 13. "Into the late 90s, early 2000s, we have had a very significant drift of tree changers to the area. People that are coming out of Melbourne, and because this is such a beautiful area to live." (P01)

Quote 14. "In the 90s, when things got particularly tough commodity price wise and season wise, people had to go off farm to put food on the table." (P01)

Quote 15. "Off farm work turned out to be good, because it got food on the table. But it was also good for their mental health, because they got to be mixing with people... a lot of marriages and lives were saved, and families were saved as a result of that forced going off farm." (P01)

Quote 17. "Agriculture provides $50 \%$ of the economic industry to the [Alpine] shire and tourism provides the other $50 \%$. People who lives in the towns. Tourism is an interesting driver, probably a major driver in decreased agriculture, because the land is becoming too expensive; the tourism value of the land is increasing." (P02)

Quote 18. "You need people coming through. You need ideas. You need people who are going to be attracted to the area and do things. That makes everything hum." (P02)

EGLO indicates employees of government and local organizations; F, farmers; P, politicians; SES, social-ecological system.

Employees of government and local organizations described a landscape that had already passed through the release phase $(\Omega)$ because of a significant shock in 2006 with the tobacco industry closure. They noted that since that time there have been great efforts to find an equally prosperous crop for the region (quote 8 ), but that has not happened and the region has been unable to recover the prosperity of the past. These informants thought that any future agricultural transformation would need outside investment (quote 9), including addressing the legacy of contaminated soils from chemicals used in tobacco production (quote 10). They also thought there was considerable social resistance to change (quote 11). The pervasive view of this group was that the region was stuck in an in-between phase since the closure of the tobacco industry. We thought this narrative of the Ovens reflected an SES that was currently in the back loop of the adaptive cycle, in the reorganization phase (Fig. 4).

The politicians provided a very different interpretation of change in the Ovens SES. From their perspective, the past landscape had been based on agriculture (quote 12), but over the last 20 years or so, the region had dramatically changed. Politicians spoke of how over the past 15 years substantial numbers of people from 
outside the region had been moving into the Ovens and that these people were reinvigorating the region (quote 13). Politicians cited long-standing difficulties in farming, including financial challenges (quote 14), and thought it was a positive development that people on farms had been increasingly taking off-farm employment in recent decades because it was improving social connection, self-esteem, and overall mental health, which ultimately saved many families (quote 15). Contrarily, farmers considered these newcomers, who are typically lifestyle property owners, as a threat to their conceptualization of the Ovens as an agricultural landscape. One reason the "lifestylers" were regarded as a threat was because there would be less land available for largescale agriculture and the available land was becoming too expensive for farmers to purchase (quote 16).

Fig. 4. Overlay of employees of government and local organizations' narrative onto the adaptive cycle. The employees of government and local organizations' narrative of the local social-ecological system aligned with the early $\alpha$ phase after having collapsed from an agricultural landscape (collapse from $\mathrm{K})$. The employees of government and local organizations' narrative spanned a shorter period of time than that of the other informant groups.

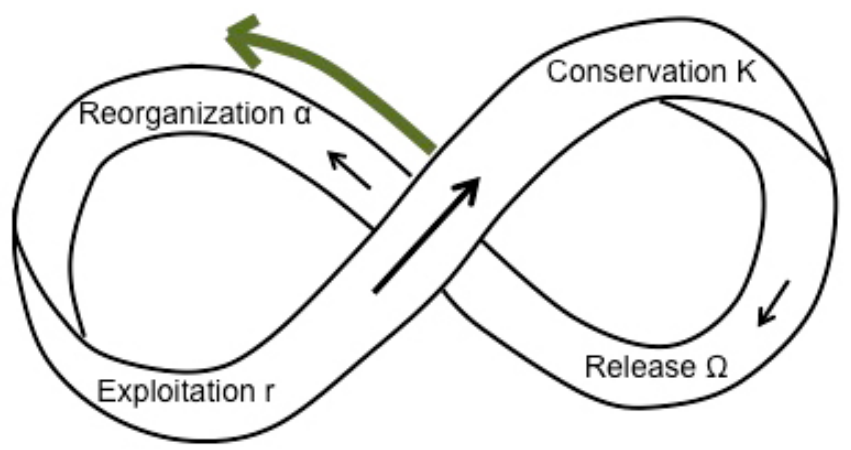

Overlaying this part of the politicians' narrative on the adaptive cycle suggested that they thought the Ovens SES had collapsed nearly 20 years ago and then reorganized into a multifunctional landscape. This multifunctional landscape was thought to have a more balanced economy based on agriculture, tourism (quote 17), and services as well as a more heterogeneous society with a more stimulating diversity of values and ideas, and a more balanced economic base (quote 18; Fig. 5).

\section{Resolving the contradictory interpretations of landscape change} in the Ovens

Our interpretation of the Ovens SES is that it is currently in the exploitation phase of a newly reorganized landscape (Fig. 6), which is consistent with the politicians' narrative (Fig. 5). To explain our interpretation, we start at the point of European settlement and continue to the present (Allison and Hobbs 2004), drawing upon a time line (Fig. 7) and the key data where appropriate to substantiate it.
Fig. 5. Overlay of politicians' narrative onto the adaptive cycle. The politicians' narrative aligned with the very early $r$ phase: the SES had collapsed from an agricultural landscape in the mid-1990s (collapse from K), had been reorganizing between the late 1990s and the late 2000s (moving through $\Omega$ and $\alpha$ ), and was currently a multifunctional landscape. SES indicates socialecological system.

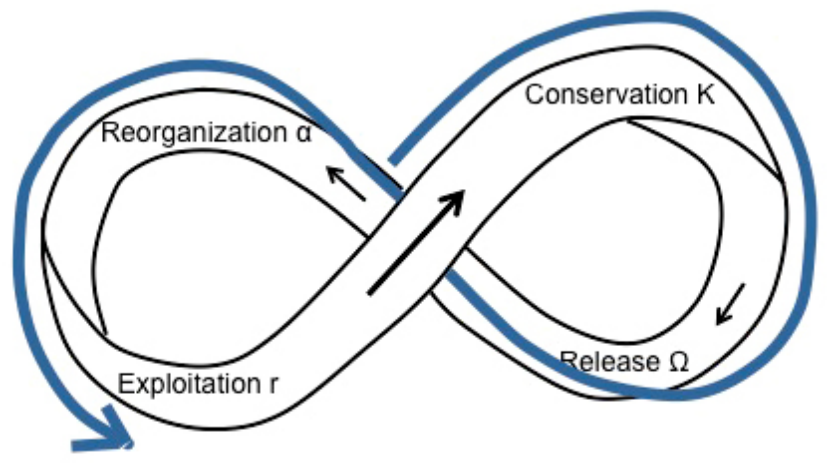

Fig. 6. Overlay of our analysis onto the adaptive cycle. Our analysis suggests that the local SES is in the early $r$ phase. The local SES had more than a century in the previous $r$ phase (points $\mathrm{x}$ and $\mathrm{y}$ ), collapsed as an agricultural landscape in the early 1990s (collapse from K, point z), was reorganizing between 1995 and 2005 (back loop, point G), and is in the early $r$ phase as a multifunctional landscape. SES indicates socialecological system.

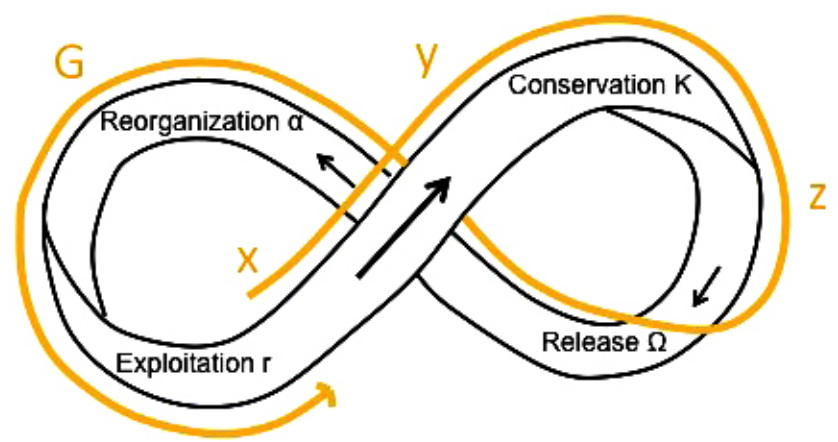

At the time of European settlement, the Ovens region was in the phase of the adaptive cycle (Fig. 6, point $\mathrm{x}$ ). We assumed that colonial settlement transformed the SES; new people arrived, eventually in large numbers, and displaced the Indigenous peoples; new animals were introduced, including today's many feral pests; land, especially the fertile river flats, was cleared of native forests for agriculture; and native vegetation was removed to provide timber for a gold mining boom, housing, and bridges (Whittaker 1963, Race et al. 2012). 
Fig. 7. Timeline of key change events in the Ovens SES from European settlement (1820s) to present. The key change events are organized into the phases of the adaptive cycle that our analysis suggests that they occurred in. SES indicates socialecological system.

\begin{tabular}{|c|c|c|}
\hline $\begin{array}{l}\text { ADAPTIVE CYCLE } \\
\text { PHASE }\end{array}$ & TIME PERIOD & EVENT \\
\hline $\begin{array}{l}\text { Not examined in this } \\
\text { research }\end{array}$ & Pre $1820 \mathrm{~s}$ & Indigenous occupation \\
\hline Exploitation (r) & $\begin{array}{c}1820 \mathrm{~s} \\
1850 \mathrm{~s} \& 1860 \mathrm{~s} \\
\text { Early } 1900 \mathrm{~s} \\
1930 \mathrm{~s} \\
1960 \mathrm{~s} \\
\text { Early 1970s } \\
1980 \mathrm{~s}\end{array}$ & $\begin{array}{l}\text { Colonization, settlement, grazing agriculture } \\
\text { Victorian gold rush } \\
\text { First forest plantations } \\
\text { Tobacco production introduced } \\
\text { Agricultural prosperity in tobacco, beef, } \\
\text { sheep, and dairy } \\
\text { Myrtleford Sawmill opened } \\
\text { Wine production increased }\end{array}$ \\
\hline Conservation (K) & $\begin{array}{l}1992 \\
1994\end{array}$ & $\begin{array}{l}\text { Agri-tourism began with wineries } \\
\text { Milawa Gourmet food region established } \\
\text { Deregulation of tobacco industry }\end{array}$ \\
\hline $\begin{array}{l}\text { Release \& } \\
\text { Reorganization } \\
(\Omega \& \alpha)\end{array}$ & $\begin{array}{l}1996-2007 \\
2003-2010 \\
2005 \\
\text { Mid } 2000 \text { s } \\
2006\end{array}$ & $\begin{array}{l}\text { No profit in beef production } \\
\text { Drought } \\
\text { Tobacco being grown for two companies } \\
\text { Myrtleford Sawmill restructured } \\
\text { Tobacco industry closed }\end{array}$ \\
\hline Exploitation (r) & $\begin{array}{c}2009 \\
2011 \\
2007-2012\end{array}$ & $\begin{array}{l}\text { Black Saturday bushfires } \\
\text { Tourism North East organization established } \\
\text { to promote tourism } \\
\text { Decline in wine industry profits in Australia }\end{array}$ \\
\hline
\end{tabular}

In the century that followed European settlement, the Ovens was an agriculturally focused landscape, and we suggest it was in the front loop of the adaptive cycle. Agriculture expanded, including into dairying and viticulture, and intensified. The mining boom and then bust left an important legacy in terms of a much larger population, increased wealth, and increased infrastructure, but also polluted land and streams and large areas where vegetation and soils were disturbed and that are now dominated by introduced weeds. Railways and a substantial road network were constructed. Forestry and related wood products became an important industry; and by the mid-1900s, manufacturing of other primary products, including milk, was important in terms of employment and incomes (Paech 2008, Race et al. 2012). The government subsidized land clearing, and nonnative, perennial grasses were broadly introduced as feed for grazing livestock. Poor soil conservation and increased runoff as a result of the clearing of native vegetation led to extensive erosion from paddocks and gullies (Race et al. 2012). During this period, we suggest the region was in the exploitation phase of the adaptive cycle (Fig. 6, point y). Tobacco was an important industry by the middle of the 20 th century and contributed to high levels of profitability for farmers that permeated most aspects of society (Tobacco Co-operative of
Victoria 2014). Indeed, farmers described the period up to the 1980 s in halcyon terms.

Our analysis of census data confirms the interpretation of the Ovens in the 20th century as principally an agricultural landscape, at least until the mid-1990s. For example, agriculture and related manufacturing were the industry sectors employing the largest percentage of the employed population in 1986: $17 \%$ and $18 \%$, respectively (Australian Bureau of Statistics 1986). By comparison, the next highest sector was retail trades, employing $15 \%$ in 1986 , followed by health and community services, employing $12 \%$ in 1986, and others, such as tourism, government, and construction, which each employed around 5\% of the population. Reflecting the influence of a prosperous agricultural sector, the population of the region continued to increase from 51,048 in 1991 to 56,445 in 1996 (Australian Bureau of Statistics 1991, 1996).

As others have found, it is typically difficult to identify tipping points (Christensen and Krogman 2012, Sinclair et al. 2014), but our analysis of the available data suggests that somewhere in the decade between the late 1980s and early 1990s, the Ovens entered a period of transition largely as a result of the decline of agriculture. We suggest that this transition represents the end of the conservation phase (Fig. 6, point z). Both the farmers and politicians agreed on the challenges that agriculture had been experiencing during this time; returns from agriculture declined, which impacted livelihoods, lifestyles, and the movement of people, including the loss of jobs on farms and young people leaving the region. Our analysis of the census data supports these interpretations of SES change: there was a substantial decline in the proportion of the workforce employed in agriculture and the relative importance of other industries as employers increased, and did so to the extent that there was no longer a single dominant industry sector.

Between 1986 and 2011 the percentage of the population employed in agriculture and manufacturing, mostly linked to primary production, declined significantly. The percentage of the population employed in agriculture and manufacturing was $17 \%$ and $18 \%$, respectively, in $1986 ; 12 \%$ and $17 \%$ in 2006 ; and $10 \%$ and $11 \%$ in 2011 (Australian Bureau of Statistics 1986, 2006, 2011).

As our key informants explained, the decline in agriculture affected the availability of work and the movement of people, particularly the younger cohort. For example, the Ovens population declined from 56,445 in 1996 to 44,617 in 2006 (Australian Bureau of Statistics 1996, 2006), a substantial 21\% decline over a decade. By comparison, the rural balance population, which we would expect to be more closely linked to agricultural success, declined more dramatically, by $55 \%$ from 41,372 in 1996 to 18,560 in 2006. Prosperous and vibrant rural communities are more likely to be able to hold and even attract younger people. Indeed, in 1986 the cohort aged 15-34 years was the largest of all in the rural balance (32.4\%), and included a much larger proportion of the population than the cohort aged 55 years and above (23.9\%; Australian Bureau of Statistics 1986). By 2006, the relative shares of the population in these cohorts had changed dramatically, with the cohort aged 15-34 years being 20.5\% and the cohort aged 55 years and above being the largest at $29.6 \%$ (Australian Bureau of Statistics 2006). 
Stewart's (2009) analysis of rural property sales data suggested that in the decade from 1995 to 2005 there was a transition away from agriculture as the main economic driver in the Ovens. According to Stewart (2009), between 1995 and 2005, the price of rural land sold in the Alpine Shire doubled from $\$ 4000 / \mathrm{Ha}$ in 1995 to $\$ 8000 / \mathrm{Ha}$ in 2005 . Stewart (2009) calculated that the price of rural land was higher than would be justified by the returns that farmers could expect to achieve from agriculture. Stewart (2009) also established that the majority of rural land sales in Alpine Shire were to people from outside the region. Stewart's (2009) research and the work of Race et al. (2012) indicate that rural land in the Ovens has increasingly been subdivided for lifestyle blocks and that those newer residents are more likely than longer term owners to place a higher value on the environmental and aesthetic values of their properties. These data are consistent with an interpretation of the Ovens transitioning from an agricultural to a multifunctional landscape in the period between 1986 and 2006, but most probably around the late 1990s.

Our consolidated interpretation is that the Ovens was in the early stages of reorganization by the mid to late 1990s and, therefore, in the back loop of the adaptive cycle (Fig. 6, point G). It is at this time where there is the most divergence between the narratives of the three informant groups. Only the politicians thought the Ovens was transitioning from a period of collapse to a different SES; i.e., a transformation was occurring. Farmers thought the Ovens had not yet reached this phase, i.e., collapse, and continued to believe agriculture underpinned the economy of the region. They acknowledged and were concerned that agriculture was struggling to find the prosperity of decades earlier. Employees of government and local organizations thought the Ovens was stuck in the back loop of the adaptive cycle, having not yet found a lucrative replacement for tobacco. By contrast, our interpretation is that these changes were occurring before the collapse of the tobacco industry and that in the early 21 st century the Ovens progressed through the back loop and has now reorganized as a multifunctional landscape (Fig. 6). The relative importance of the industries of employment has shifted away from primary production toward services, and employment is spread more evenly across industry sectors. After a substantial decline in the total population up to 2006, the population has now stabilized. For example, between 1996 and 2001, the total population decreased by $10.8 \%$ and the rural balance by $38.6 \%$ (Australian Bureau of Statistics 1996, 2001); and between 2001 and 2006 the total population and the rural balance decreased by $11.2 \%$ and $26.9 \%$, respectively (Australian Bureau of Statistics 2001, 2006). In 2006 , the total population was 44,617 , which only decreased by $0.2 \%$ in 2011 to 44,720 (Australian Bureau of Statistics 2006, 2011). Similarly, for the rural balance, in 2006 the population was 18,560 and only decreased by $3.5 \%$ to 17,911 in 2011 (Australian Bureau of Statistics 2006, 2011). In summary, after a decade of dramatic population decline, the population stabilized by 2011 , consistent with the transformation we describe above.

Informants indicated that identifying a new, profitable agricultural opportunity is improbable. Informants also highlighted the development of tourism in the region, including cellar doors and coffee shops associated with the numerous wineries in the Ovens. As Stewart (2009) demonstrated, land prices had decoupled from agricultural production values in that despite low levels of profitability in agriculture (e.g., low profits from beef cattle), rural land prices doubled over the 1995-2005 decade (quote 14). These cultural features reflect the extent of a shift away from production-oriented values toward lifestyle and other amenities.

\section{DISCUSSION}

\section{Reflections on findings}

Our findings of multiple, contradictory narratives of change might be a common occurrence in rural landscapes. Williams and Schirmer (2012) found that it is often difficult for local residents to understand and make sense of larger landscape-scale change where they live. Local residents tend to rely on the "felt" experience of change (Slootweg et al. 2001) and take action to address the trends they feel and experience (Williams and Schirmer 2012). Informants' responses to the tobacco industry closure as a threat to prosperity in the Ovens could be described as a reaction to a felt experience. Having said that, there were mixed responses to the food bowl concept. It became clear to the research team that those backing the food bowl proposal were unable to see the longer transition to a multifunctional landscape and that general lack of interest in the food bowl concept based on the exploitation of groundwater also reflected the extent to which the Ovens had transitioned to a multifunctional landscape.

Indeed, our view is that the closure of the tobacco industry and the subsequent failure to identify a new opportunity for profitable agriculture are not going to lead to a collapse of the local economy: the Ovens economy has already collapsed and reorganized. The failure of key actors to identify or accept that the Ovens has transformed has potentially important implications. Those conceptualizing the Ovens as a productionoriented landscape underpinned by agriculture either occupy positions of authority or are influential in key local organizations, including local government, watershed organizations, farmer organizations, and water management agencies. For example, during a recent review of local government planning schemes, farmers advocated for zoning that protected agricultural values by controlling subdivision of rural properties. Although rules preventing subdivision may help retain amenity values such as quality of views and limited traffic, they may also constrain population growth and lead to higher rates being charged by local governments (i.e., a smaller number of potential ratepayers to share costs) and higher land prices where subdivision is permitted that reduce affordability of housing. To the extent that powerful actors are able to convince governments to invest public funds to support agriculture, including initiatives such as the food bowl concept, there is also the potential for the misallocation of scarce resources that could be used to address other needs.

\section{Reflections on approach}

The adaptive cycle was a useful aid in visualizing and organizing (i.e., exposing) and then comparing (i.e., resolving) discourses on landscape change. The FAS (Kok et al. 2006a, $b$ ) was a useful framework for coding interview data, and the resulting narratives highlighted the heterogeneity of perspectives that is vital to understanding social dynamics (Rawluk and Godber 2011, Fabinyi et al. 2014). Being able to observe contradictory narratives provided a powerful aid for reflection about how local people can interpret a landscape differently.

There is value in taking a medium-term view when approaching the challenges of interpreting change in an SES based on multiple forms of data. Although much research has considered 
adaptation to sudden events, such as a flood (Adger et al. 2005, Kuhlicke 2013), or very long time frames, such as the span of civilizations (Redman and Kinzig 2003), there is value in considering the perspective of "lived change" such as is experienced in a working life or a generation as we have done. The advantages of the medium term are that substantial change can occur and become evident over a generation; informants can provide reliable information about the recent past. However informants should be from different interest and age groups, and secondary data should be applied to help form a consolidated interpretation of change.

\section{IMPLICATIONS AND CONCLUSION}

Labeling of the adaptive cycle phases should be revised to more accurately reflect what happens in social systems. The labels applied to describe the phases of the adaptive cycle have not changed since the original application with ecological systems. Our analysis suggested that the Ovens had reorganized into a multifunctional landscape, with a more balanced employment structure and less reliance on the exploitation of natural resources, suggesting the Ovens has transformed into a potentially more resilient landscape (Wilson 2014). For example, with employment spread across several industry sectors, it is less likely the Ovens would experience the boom and bust cycles typical of many resource-dependent communities (Auty 1997). Labeling the current phase of the Ovens system as exploitation, therefore, seems inappropriate and distinctly mismatched with the characteristics of a multifunctional landscape. It is also possible that other SESs experiencing a future transition from an economic base dependent on natural resource exploitation would do so based on renewable energy.

Social memory and power are two aspects of resilience thinking that require the ability to unravel discourse of the past, present, and future, and are currently underdeveloped (Davidson 2010, Nykvist and von Heland 2013, Kuhlicke 2013, Fabinyi et al. 2014, Cameron et al. 2015). From our findings, one might regard the interpretations of the past landscape as social memory. For example, we wondered why the employees of government and local organizations did not have social memory of the region, and what the implications of that would be for decision making. Additionally, recent scholarship has been urging the examination of relationships of power in resilience thinking research, in particular the gap in resilience thinking on how to handle discursive power relationships. Our use of the adaptive cycle, wherein discourse can be observed and compared, could be a vital starting point for those researchers examining relationships of power.

Responses to this article can be read online at: http://www.ecologyandsociety.org/issues/responses. $\mathrm{php} / 8245$

\section{Acknowledgments:}

We wish to express our appreciation to the National Centre for Groundwater Research and Training for financially supporting this research and to Charles Sturt University for a scholarship to write this paper. We thank Simon McDonald for his support with handling the census data and generating the case study map. We thank two anonymous reviewers for their invaluable comments on the manuscript. It is with great gratitude that we thank informants for sharing their experience of landscape change with us.

\section{LITERATURE CITED}

Abel, N., D. H. M. Cumming, and J. M. Anderies. 2006. Collapse and reorganization in social-ecological systems: questions, some ideas, and policy implications. Ecology and Society 11(1):17. [online] URL: http://www.ecologyandsociety.org/vol11/iss1/ art17!

Adger, W. N., N. W. Arnell, and E. L. Tompkins. 2005. Successful adaptation to climate change across scales. Global Environmental Change 15:77-86. http://dx.doi.org/10.1016/j.gloenvcha.2004.12.005

Agrawal, A., and C. C. Gibson. 1999. Enchantment and disenchantment: the role of community in natural resource conservation. World Development 27(4):629-649. http://dx.doi. org/10.1016/s0305-750x(98)00161-2

Allison, H. E., and R. J. Hobbs. 2004. Resilience, adaptive capacity, and the "Lock-in Trap" of the Western Australian agricultural region. Ecology and Society 9(1):3. [online] URL: http://www.ecologyandsociety.org/vo19/iss1/art3/

Andersen, I. E., and B. Jaeger. 1999. Scenario workshops and consensus conferences: towards more democratic decisionmaking. Science and Public Policy 26(5):331-340

Australian Bureau of Statistics. 1986. Census of population and housing: 1986 time series data. Government of Australia, Canberra, Australian Capital Territory, Australia.

Australian Bureau of Statistics. 1991. Census of population and housing: 1991 time series data. Government of Australia, Canberra, Australian Capital Territory, Australia.

Australian Bureau of Statistics. 1996. Census of population and housing: 1996 time series data. Government of Australia, Canberra, Australian Capital Territory, Australia.

Australian Bureau of Statistics. 2001. Census of population and housing: 2001 basic community profile data. AusStats database. Government of Australia, Canberra, Australian Capital Territory, Australia.

Australian Bureau of Statistics. 2006. Census of population and housing: 2006 basic community profile data. AusStats database. Government of Australia, Canberra, Australian Capital Territory, Australia.

Australian Bureau of Statistics. 2011. Census of population and housing: 2011 basic community profile data. AusStats database. Commonwealth of Australia, Canberra, Australian Capital Territory, Australia.

Auty, R. M. 1997. Natural resource endowment, the state and development strategy. Journal of International Development 9 (4):651-663. http://dx.doi.org/10.1002/(SICI)1099-1328(199706) 9:4<651::AID-JID474>3.0.CO;2-4

Biernacki, P., and D. Waldorf. 1981. Snowball sampling: problems and techniques of chain referral sampling. Sociologia Ruralis 10 (2):141-163. 
Bowen, G. A. 2009. Document analysis as a qualitative research method. Qualitative Research Journal 9(2):27-40. http://dx.doi. org/10.3316/qrj0902027

Cameron, E., R. Mearns, and J. T. McGrath. 2015. Translating climate change: adaptation, resilience, and climate politics in Nunavut, Canada. Annals of the Association of American Geographers 105(2):1-10. http://dx.doi.org/10.1080/00045608.2014.973006

Christensen, L., and N. Krogman. 2012. Social thresholds and their translation into social-ecological management practices. Ecology and Society 17(1):5. http://dx.doi.org/10.5751/ES-04499-170105

Creswell, J. W. 2009. Research design: qualitative, quantitative, and mixed methods approaches. Third edition. Sage, Thousand Oaks, California, USA.

Commonwealth Scientific and Industrial Research Organisation (CSIRO). 2008. Water availability in the Ovens. A report to the Australian Government from the CSIRO Murray-Darling Basin Sustainable Yields Project. Government of Australia, Canberra, Australian Capital Territory, Australia.

Curtis, A., E. Herreria, and S. Kelson. 2003. Murrumbidgee socioeconomic profile. Bureau of Rural Sciences, Government of Australia, Canberra, Australian Capital Territory, Australia.

Davidson, D. J. 2010. The applicability of the concept of resilience to social systems: some sources of optimism and nagging doubts. Society \& Natural Resources 23(12):1135-1149. http://dx.doi. org/10.1080/08941921003652940

Davidson, D. J. 2013. We still have a long way to go, and a short time to get there: a response to Fikret Berkes and Helen Ross. Society \& Natural Resources 26(1):21-24. http://dx.doi. org/10.1080/08941920.2012.749758

Department of Environment and Primary Industry. 2014. Water. Department of Environment and Primary Industry, Melbourne, Victoria, Australia. http://www.depi.vic.gov.au/water

Fabinyi, M. L., L. Evans, and S. J. Foale. 2014. Social-ecological systems, social diversity, and power: insights from anthropology and political ecology. Ecology and Society 19(4):28. http://dx.doi. org/10.5751/ES-07029-190428

Flyvbjerg, B. 1998. Rationality \& power: democracy in practice. University of Chicago Press, Chicago, Illinois, USA.

Gadsby, S., M. Lockwood, S. Moore and A. Curtis. $2013 a$. Tasmanian midlands socio-economic profile. University of Tasmania, Hobart, Tasmania, Australia.

Gadsby, S., M. Lockwood, S. Moore, A. Curtis, and S. Joyce. 2013b. Australian Alps socio-economic profile. University of Tasmania, Hobart, Tasmania, Australia.

Gosnell, H., and J. Abrams. 2011. Amenity migration: diverse conceptualizations of drivers, socioeconomic dimensions, and emerging challenges. GeoJournal 76:303-322. http://dx.doi. org/10.1007/s10708-009-9295-4

Goulburn-Murray Water. 2012. Upper Ovens River Water Supply Protection Area Water Management Plan. Tatura, Victoria, Australia.
Gunderson, L. H., and C. S. Holling, editors. 2002. Panarchy: understanding transformations in human and natural systems. Island Press, Washington, D.C., USA.

Kok, K., M. Patel, D. S. Rothman, and G. Quaranta. $2006 a$. Multi-scale narratives from an IA perspective: part II. Participatory local scenario development. Futures 38(3):285-211. http://dx.doi.org/10.1016/j.futures.2005.07.006

Kok, K., D. S. Rothman, and M. Patel. 2006b. Multi-scale narratives from an IA perspective: part I. European and Mediterranean scenario development. Futures 38(3):261-284. http://dx.doi.org/10.1016/j.futures.2005.07.001

Kuhlicke, C. 2013. Resilience: a capacity and a myth: findings from an in-depth case study in disaster management research. Natural Hazards 67(1):61-66. http://dx.doi.org/10.1007/s11069-010-9646$\mathrm{y}$

Kumar, C. 2005. Revisiting 'community' in community-based natural resource management. Community Development Journal 40(3):275-285. http://dx.doi.org/10.1093/cdj/bsi036

Kvale, S. 1996. Interviews: an introduction to qualitative research interviewing. Sage, Thousand Oaks, California, USA.

Lockwood, M., M. Mitchell, S. A. Moore, and S. Clement. 2014. Biodiversity governance and social-ecological system dynamics: transformation in the Australian Alps. Ecology and Society 19 (2):13. http://dx.doi.org/10.5751/ES-06393-190213

Lyon, C., and J. R. Parkins. 2013. Toward a social theory of resilience: social systems, cultural systems, and collective action in transitioning forest-based communities. Rural Sociology 78 (4):528-549. http://dx.doi.org/10.1111/ruso.12018

Nykvist, B., and J. von Heland. 2014. Social-ecological memory as a source of general and specified resilience. Ecology and Society 19(2):47. http://dx.doi.org/10.5751/ES-06167-190247

Paech, A. 2008. Agricultural resources in North East Victoria: the Alpine valleys. Department of Primary Industries, Melbourne, Victoria, Australia.

Peterson, G. D., T. D. Beard, Jr., B. E. Beisner, E. M. Bennett, S. R. Carpenter, G. S. Cumming, C. L. Dent, and T. D. Havlicek. 2003. Assessing future ecosystem services: a case study of the Northern Highlands Lake District, Wisconsin. Conservation Ecology 7(3):1. [online] URL: http://www.consecol.org/vol7/iss3/ art1/

Poland, B. 2002. Transcription quality. Pages 629-649 in J. F. Gubrium and J. A. Holstein, editors. Handbook of interview research: context \& method. Sage, Thousand Oaks, California, USA.

Race, D., A. Curtis, G. Kyle, W. Merritt, and G. Park. 2012. Exploring landscape history through integrated participatory research: experiences from Victoria. Pages 145-156 in T. Lefroy, A. Curtis, A. Jakeman, and J. McKee, editors. Landscape logic: integrating science for landscape management. Commonwealth Scientific and Industrial Research Organisation, Collingwood, Victoria, Australia.

Rawluk, A., and A. Godber. 2011. Widening the scope of scenario planning in small communities: a case study use of an alternative 
method. Ecology and Society 16(1):11. [online] URL: http://www. ecologyandsociety.org/vol16/iss1/art11/

Redman, C. L., and A. P. Kinzig. 2003. Resilience of past landscapes: resilience theory, society, and the longue durée. Conservation Ecology 7(1):14. [online] URL: http://www. consecol.org/vol7/iss1/art14/

Reed, M. S., A. Graves, N. Dandy, H. Posthumus, K. Hubacek, J. Morris, C. Prell, C. H. Quinn, and L. C. Stringer. 2009. Who's in and why? A typology of stakeholder analysis methods for natural resource management. Journal of Environmental Management 90:1933-1949. http://dx.doi.org/10.1016/j. jenvman.2009.01.001

Richards, L. 2009. Handling qualitative data: a practical guide. Second edition. Sage, Thousand Oaks, California, USA.

Sanders, I. T. 1960. The community social profile. American Sociological Review 25(1):75-77. http://dx.doi.org/10.2307/2088950

Sinclair, K., A. Curtis, E. Mendham, and M. Mitchell. 2014. Can resilience thinking provide useful insights for those examining efforts to transform contemporary agriculture? Agriculture and Human Values 31:371-384. http://dx.doi.org/10.1007/s10460-014-9488-4

Slootweg, R., F. Vanclay, and M. van Schooten. 2001. Function evaluation as a framework for the integration of social and environmental impact assessment. Impact Assessment and Project Appraisal 19(1):19-28 http://dx.doi.org/10.3152/147154601781767186

Stewart, H. 2009. Socio-economic dimensions of planted forests in changing landscapes: exploring the future for forestry in south east Australia. Dissertation. Charles Sturt University, Albury, New South Wales, Australia.

Tobacco \& Associated Farmers Co-operative (TAFCO). 2008. Annual report to members. TAFCO Rural Supplies, Myrtleford, Victoria, Australia.

Tobacco \& Associated Farmers Co-operative (TAFCO). 2009. Annual report to members 2008-2009. TAFCO Rural Supplies, Myrtleford, Victoria, Australia.

Tobacco Co-Operative of Victoria. 2014. Tobacco growing in Victoria. Tobacco Co-Operative of Victoria, Myrtleford, Victoria, Australia. [online] URL: http://www.alpinelink.com.au/ tobaccoproduction/index.shtml

Walker, B. H., N. Abel, J. M. Anderies, and P. Ryan. 2009. Resilience, adaptability, and transformability in the GoulburnBroken Catchment, Australia. Ecology and Society 14(1):12. [online] URL: http://www.ecologyandsociety.org/vol14/iss1/ $\underline{\operatorname{art12l}}$

Walker, B., S. Carpenter, J. Anderies, N. Abel, G. S. Cumming, M. Janssen, L. Lebel, J. Norberg, G. D. Peterson, and R. Pritchard. 2002. Resilience management in social-ecological systems: a working hypothesis for a participatory approach. Conservation Ecology 6(1):14. [online] URL: http://www. consecol.org/vol6/iss1/art14

Walker, B. H., L. H. Gunderson, A. P. Kinzig, C. Folke, S. R. Carpenter, and L. Schultz. 2006. A handful of heuristics and some propositions for understanding resilience in social-ecological systems. Ecology and Society 11(1):13. [online] URL: http://www. ecologyandsociety.org/vol11/iss1/art13

Walker, B., and J. A. Meyers. 2004. Thresholds in ecological and social-cological systems: a developing database. Ecology and Society 9(2):3. [online] URL: http://www.ecologyandsociety.org/ vol9/iss $2 /$ art $3 /$

Walker, B., and D. Salt. 2012. Resilience practice: building capacity to absorb disturbance and maintain function. Island Press, Washington, D.C., USA. http://dx.doi.org/10.5822/978-1-61091-231-0

Wangaratta and Alpine Shire. 2010. Alpine Valleys Agrifood: growing at a higher level. Agrifood Prospectus. Rural City of Wangaratta and Alpine Shire, Bright, Victoria, Australia.

Whittaker, D. M. 1963. Wangaratta. Wangaratta City Council, Wangaratta, Victoria, Australia.

Williams, K. J. H., and J. Schirmer. 2012. Understanding the relationship between social change and its impacts: the experience of rural land use change in southeastern Australia. Journal of Rural Studies 28(4):538-548. http://dx.doi.org/10.1016/j. jrurstud.2012.05.002

Wilson, G. A. 2014. Community resilience: path dependency, lock-in effects and transitional ruptures. Journal of Environmental Planning and Management 57(1):1-26. http://dx.doi. org/10.1080/09640568.2012.741519 